\title{
Atypical Lipomatous Tumor/Well-Differentiated Liposarcoma with Myxoid Stroma in a Hereditary Retinoblastoma Survivor
}

\author{
Travis Peck $^{a}$ Kalla A. Gervasio ${ }^{a}$ Paul J.L. Zhang ${ }^{b}$ Carol L. Shields ${ }^{a, c}$ Sara E. Lally ${ }^{a, c}$ \\ Ralph C. Eagle Jr. ${ }^{\text {a d }}$ Tatyana Milman ${ }^{a, d}$ \\ a Department of Ophthalmology, Wills Eye Hospital, Sidney Kimmel Medical College of Thomas Jefferson \\ University, Philadelphia, PA, USA; ${ }^{b}$ Department of Pathology and Laboratory Medicine, Hospital of the University \\ of Pennsylvania, Perelman School of Medicine, Philadelphia, PA, USA; ' ${ }^{O}$ cular Oncology Service, Wills Eye Hospital,

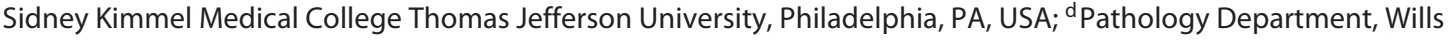 \\ Eye Hospital, Sidney Kimmel Medical College Thomas Jefferson University, Philadelphia, PA, USA
}

\section{Established Facts}

- Prognosis and management of liposarcoma is dependent on anatomic location, resectability, and liposarcoma type.

- Atypical lipomatous tumor/well-differentiated liposarcoma (ALT/WDL) with myxoid stroma can morphologically resemble myxoid liposarcoma.

- Molecular genetic studies are helpful in distinguishing between ALT/WDL with myxoid stroma and myxoid liposarcoma.

\section{Novel Insights}

- Most previously reported orbital myxoid liposarcomas have not been evaluated by molecular genetic methods.

- DDIT3 amplification, previously documented in dedifferentiated liposarcoma with myxoid stroma can be also observed in ALT/WDL with myxoid stroma.

\section{Keywords}

Well-differentiated liposarcoma - Atypical lipomatous tumor - Liposarcoma - Liposarcoma with myxoid stroma . Orbit - Orbital liposarcoma · MDM2 - DDIT3 · RB1 ·

Retinoblastoma · Myxoid liposarcoma

\begin{abstract}
Atypical lipomatous tumor/well-differentiated liposarcoma (ALT/WDL) is an indolent, locally aggressive mesenchymal neoplasm, most often confined to the lower extremities and retroperitoneum and rarely identified in the orbit. Diagnosis of ALT/WDL can be challenging due to its frequent morphologic overlap with benign adipose lesions and other more
\end{abstract}

\section{KARGER}

(C) 2019 S. Karger AG, Basel

E-Mail karger@karger.com

www.karger.com/oop
Tatyana Milman, MD

Department of Pathology, Wills Eye Hospital

840 Walnut Street

Philadelphia, PA 19107 (USA)

E-Mail tmilman@willseye.org 
aggressive liposarcoma subtypes, including myxoid liposarcoma. We describe a 26-year-old female with a history of hereditary retinoblastoma and external-beam radiotherapy to the orbit, who developed orbital liposarcoma. Although initial morphologic assessment raised the consideration of myxoid liposarcoma, subsequent fluorescein in situ hybridization studies demonstrated MDM2 and DDIT3 coamplification without DDIT3 rearrangement, supporting the diagnosis of ALT/WDL with myxoid stroma. The literature review of previously reported orbital myxoid liposarcomas revealed a morphologic overlap of documented tumors with ALT/WDL, dedifferentiated liposarcoma, and pleomorphic liposarcoma with myxoid stroma as well as an absence of immunohistochemical and molecular genetic data supportive of the diagnosis of myxoid liposarcoma. This case emphasizes the potential overlap of ALT/WDL with myxoid liposarcoma and the increasing importance of molecular genetic studies in the diagnosis, prognosis, and management of orbital liposarcoma.

(c) 2019 S. Karger AG, Basel

\section{Introduction}

Liposarcoma, the most common soft-tissue sarcoma in adults, is infrequently found in the orbit [1]. Prognosis and management of liposarcoma is dependent on anatomic location, resectability, and subtype [2,3]. Well-differentiated liposarcoma (WDL), the most common subtype, is characterized by locally aggressive behavior without metastatic potential, unless dedifferentiation occurs. The term "atypical lipomatous tumor (ALT)" has been introduced to emphasize the favorable prognosis of WDL in the head and neck, trunk, and extremities [2,3]. ALT/ WDL may contain abundant myxoid stroma, mimicking other myxoid neoplasms, including myxoid liposarcoma [2-4]. Unlike ALT/WDL, myxoid liposarcoma has welldocumented potential for metastasis, particularly in higher-grade lesions. Identification of distinct recurrent molecular genetic alterations in ALT/WDL and myxoid liposarcoma has improved our ability to discriminate between these prognostically different tumors [2-4]. We describe a patient with bilateral hereditary retinoblastoma previously treated with external-beam radiotherapy to the orbits, who developed ALT/WDL with prominent myxoid stroma, initially raising a consideration of myxoid liposarcoma. We discuss the ancillary studies helpful in distinguishing between ALT/WDL and myxoid liposarcoma as well as the prognostic and management implications of accurate diagnosis.

\section{Case Report}

A 26-year-old female was found on screening magnetic resonance imaging (MRI) to have a homogeneous, enhancing intraconal mass conforming to the globe and filling the left orbit, initially interpreted as a lymphatic-venous malformation (Fig. 1). The patient's history revealed germline bilateral retinoblastoma diagnosed at 3 months of age and management with external-beam radiotherapy to both eyes, systemic chemotherapy, and subsequent enucleation of the right eye and iodine-125 (I-125) plaque brachytherapy in the left eye. Three years previously, she was diagnosed with a high-grade postradiation osteosarcoma of the right orbit and paranasal sinuses, which was managed with orbital exenteration and systemic chemotherapy.

On our evaluation, there was notable bilateral orbital hypoplasia and a healed right exenterated socket (Fig. 1). Visual acuity was $20 / 40$ in the left eye and the color plates were normal. Confrontational visual fields were full and there was no limitation of extraocular motility. Hertel exophthalmometry demonstrated mild left proptosis, when compared to previous external examinations. A fine-needle aspiration biopsy of the left orbital mass was nondiagnostic and followed by an open diagnostic biopsy and orbital tumor debulking.

Microscopic evaluation demonstrated soft-tissue fragments containing an infiltrate of spindle-to-ovoid cells in the background of abundant myxoid stroma, fine collagen fibers and delicate, short, focally branching capillaries (Fig. 1). Infiltration of skeletal muscle was present. Occasional lipoblasts and mature-appearing adipocytes were noted. Mitotic figures were not conspicuous $(<4$ in 10 high-power fields). No significant nuclear pleomorphism or necrosis was identified (Fig. 1). Immunohistochemical stains showed that the neoplastic cells expressed CD34 and S-100 (partial, most prominent in lipoblasts and adipocytes), with a Ki-67 proliferative index of $1-2 \%$. Fluorescein in situ hybridization (FISH) demonstrated MDM2 (12q15) and DDIT3 (12q13) coamplification (Fig. 1). There was no evidence of DDIT3 translocation. The aggregate findings were diagnostic of ALT/WDL with either myxoid stroma or low-grade myxofibrosarcoma-like dedifferentiation. Due to the lack of morphologic features of a low-grade myxofibrosarcoma, such as significant nuclear atypia/pleomorphic cells and the characteristic curvilinear vasculature, we diagnosed this neoplasm as ALT/WDL with myxoid stroma, also known as myxoid ALT/WDL.

Various management options for control of the residual orbital tumor were discussed with the patient. These included orbital exenteration and irradiation, which could potentially compromise her vision due to the proximity of the tumor to the optic nerve. Our monocular patient elected vision-sparing observation. Unfortunately, she developed a recurrent tumor 3 months later, which was morphologically similar to the previously biopsied lesion, and, additionally, contained microscopic foci of high-grade dedifferentiated liposarcoma (DDL), accounting for $5 \%$ of the lesion (Fig. 2). FISH studies of the recurrent tumor demonstrated CDK4 gene amplification. She will follow-up with the Oncology Department for a decision on the definitive treatment of her residual orbital disease, including potential enrollment into clinical trials targeting CDK4 amplified liposarcoma.
80

Ocul Oncol Pathol 2020;6:79-86

DOI: $10.1159 / 000501523$
Peck/Gervasio/Zhang/Shields/Lally/

Eagle Jr./Milman 

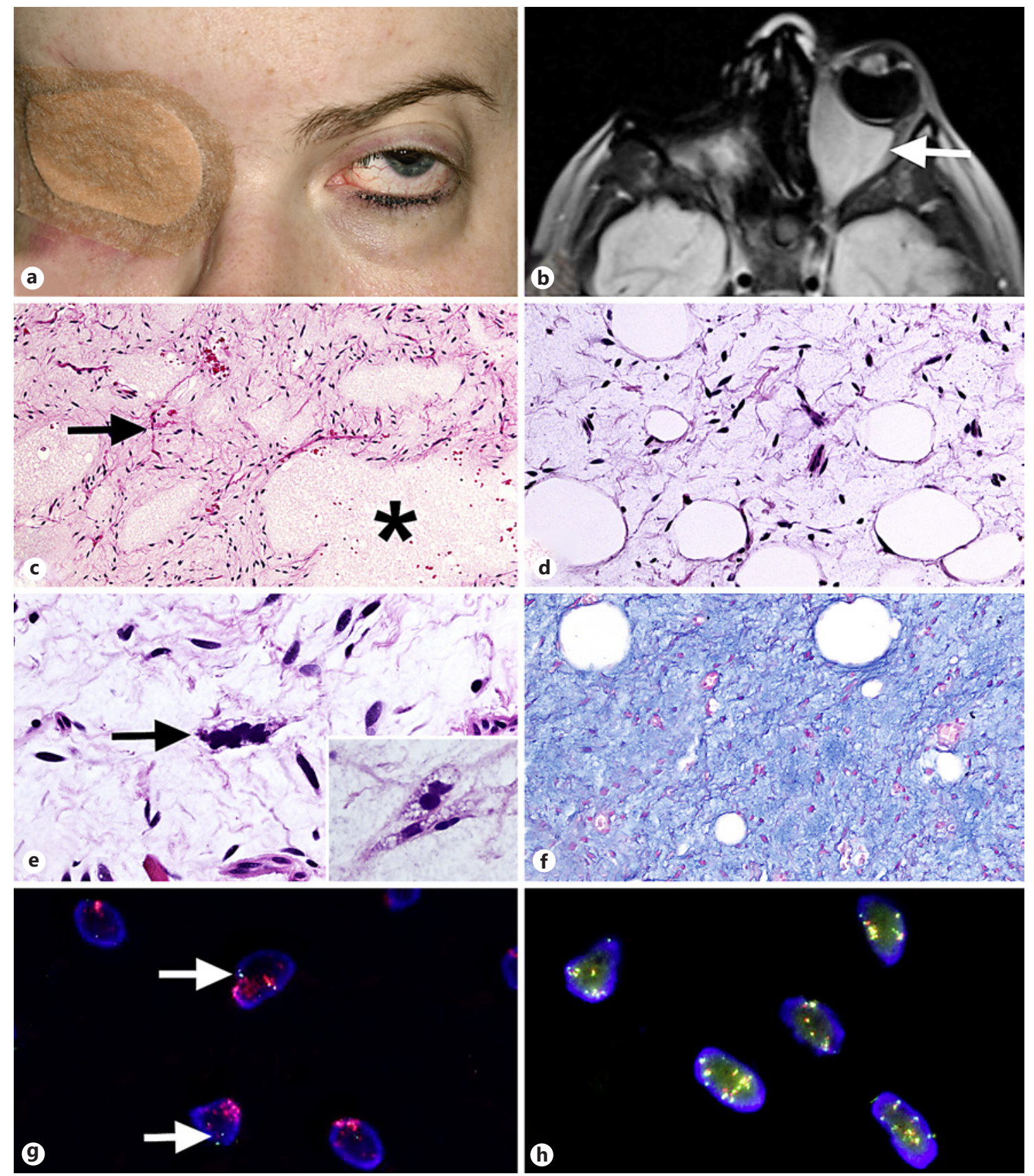

Fig. 1. Clinical, histopathologic, and cytogenetic features of initial biopsy of atypical lipomatous tumor/well-differentiated liposarcoma with myxoid stroma. a External photograph demonstrates exenterated right socket and left proptosis. b Axial MRI demonstrates absence of the right globe and orbital tissues, compatible with prior right orbital exenteration defect, and a well-circumscribed enhancing left retrobulbar mass. c The neoplasm is composed of spindle-to-ovoid cells in a background of abundant myxoid matrix and delicate intervening capillaries (arrow) with focal "pseudo-alveolar" type spaces (asterisk), reminiscent of myxoid liposarcoma. HE. $\times 25$. d The neoplastic cells have mildly pleomorphic nuclei with foci of advanced adipocytic differentiation. HE. $\times 50$. e Occasional multinucleated cells with hyperchromatic nuclei and multiple intracytoplasmic vacuoles (arrow) and lipoblasts with indented nuclei and cytoplasmic vacuoles (inset) are present. HE. $\times 500$. f Abundant myxoid stroma are highlighted. Alcian blue. $\times 50$. g Fluorescence in situ hybridization (FISH) demonstrates amplification of MDM2 (pink signal) relative to the green CEP12 centromeric signals (arrows). h FISH with breakapart probes for DDIT3 rearrangement demonstrates multiple closely apposed green and red signals, yielding multiple yellow signals, compatible with DDIT3 amplification. 

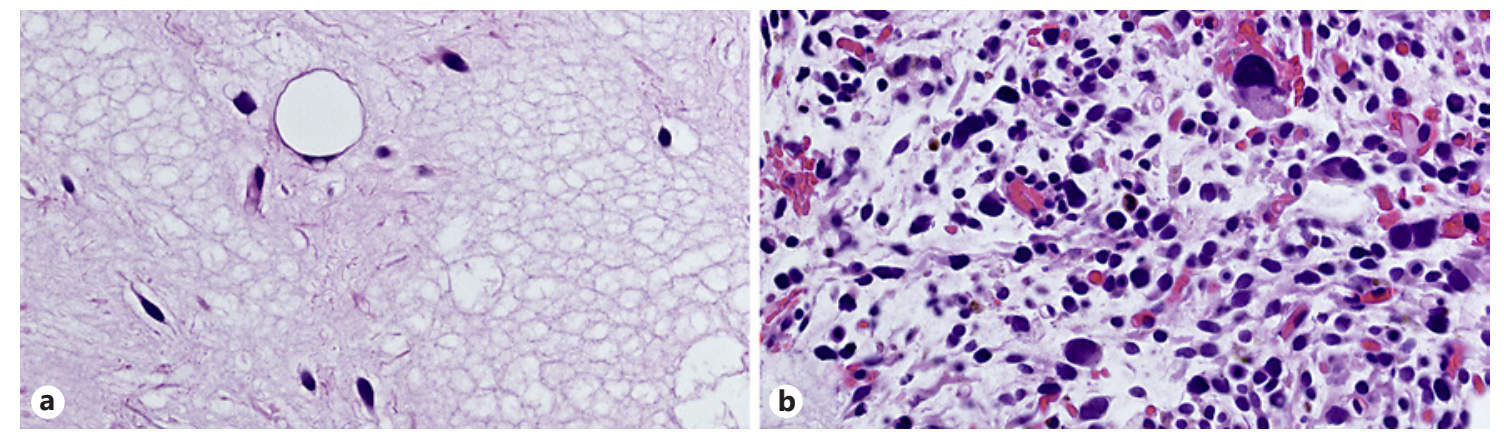

Fig. 2. Histopathologic features of a recurrent tumor. a Most of the tumor is morphologically similar to the original biopsy, featuring spindle-to-ovoid cells and vacuolated lipoblasts without appreciable nuclear atypia or pleomorphism in a background of abundant myxoid stroma, compatible with atypical lipomatous tumor/well- differentiated liposarcoma. HE. $\times 100$. b Foci of highly cellular proliferation with prominent nuclear pleomorphism, hyperchromasia, and atypia, without appreciable adipose differentiation, compatible with high-grade dedifferentiated liposarcoma, are present. HE. $\times 100$.

Table 1. Clinical and pathologic features of ATL/WDL

\begin{tabular}{|c|c|c|c|c|c|c|c|}
\hline $\begin{array}{l}\text { First author } \\
\text { [ref.], year }\end{array}$ & $\begin{array}{l}\text { Pt } \\
\text { No. }\end{array}$ & $\begin{array}{l}\text { Age, years/ } \\
\text { sex }\end{array}$ & $\begin{array}{l}\text { Presenting signs } \\
\text { and symptoms }\end{array}$ & Histopathology & $\begin{array}{l}\text { IHC/molecular } \\
\text { studies }\end{array}$ & Management & $\begin{array}{l}\text { Recurrence?/ } \\
\text { follow-up, } \\
\text { months }\end{array}$ \\
\hline \multirow{6}{*}{$\begin{array}{l}\text { Cai } \\
{[7], 2001}\end{array}$} & 1 & $34 / \mathrm{M}$ & proptosis & ATL/WDL, inflammatory & not performed & marginal excision & Yes $(\times 6) / 204$ \\
\hline & 2 & $52 / \mathrm{F}$ & proptosis & ATL/WDL, spindle cell & not performed & marginal excision & $\mathrm{No} / 53$ \\
\hline & 3 & $35 / \mathrm{F}$ & $\begin{array}{l}\text { orbital pain, proptosis, } \\
\text { diplopia }\end{array}$ & $\begin{array}{l}\text { ATL/WDL, lipoma-like and } \\
\text { sclerosing }\end{array}$ & not performed & exenteration & No follow-up \\
\hline & 4 & $28 / \mathrm{M}$ & proptosis, diplopia & ATL/WDL, spindle cell & not performed & exenteration, XRT & $\mathrm{No} / 13$ \\
\hline & 5 & $69 / \mathrm{M}$ & proptosis & ATL/WDL, lipoma-like & not performed & exenteration & No/108 \\
\hline & 6 & $54 / \mathrm{F}$ & proptosis & $\begin{array}{l}\text { WDL, lipoma-like and } \\
\text { sclerosing with DDL }\end{array}$ & not performed & exenteration & No follow-up \\
\hline $\begin{array}{l}\text { Stiglmayer } \\
{[26], 2003}\end{array}$ & 7 & $55 / \mathrm{F}$ & proptosis & WDL/DDL & not performed & $\begin{array}{l}\text { XRT prior to biopsy, } \\
\text { marginal excision }\end{array}$ & No follow-up \\
\hline $\begin{array}{l}\text { Rosner } \\
{[27], 2006}\end{array}$ & 8 & $24 / \mathrm{F}$ & $\begin{array}{l}\text { proptosis, extraocular } \\
\text { motility restriction }\end{array}$ & $\begin{array}{l}\text { WDL, lipoma-like, } \\
\text { inflammatory, sclerosing }\end{array}$ & $\begin{array}{l}\text { CGH: } \\
\text { 12q12-22 } \\
\text { amplification }\end{array}$ & marginal excision & Yes $(\times 1) / 24$ \\
\hline $\begin{array}{l}\text { Jakobiec } \\
{[28], 2010}\end{array}$ & 9 & $36 / \mathrm{M}$ & $\begin{array}{l}\text { proptosis, extraocular } \\
\text { motility restriction }\end{array}$ & $\begin{array}{l}\text { WDL, lipoma-like and spindle } \\
\text { cell }\end{array}$ & $\begin{array}{l}\text { IHC: } \\
\text { MDM2-positive }\end{array}$ & $\begin{array}{l}\text { observation } \\
\text { (exenteration, XRT } \\
\text { recommended) }\end{array}$ & No follow-up \\
\hline $\begin{array}{l}\text { Torrado } \\
{[29], 2011}\end{array}$ & 10 & $45 / \mathrm{M}$ & $\begin{array}{l}\text { proptosis, diplopia, } \\
\text { mild pain }\end{array}$ & WDL, lipoma-like & not performed & exenteration, XRT & $\mathrm{No} / 36$ \\
\hline $\begin{array}{l}\text { Vrcek } \\
{[30], 2014}\end{array}$ & 11 & $67 / \mathrm{M}$ & $\begin{array}{l}\text { proptosis, diplopia, } \\
\text { pain }\end{array}$ & WDL, lipoma-like & $\begin{array}{l}\text { IHC: } \\
\text { MDM2-positive } \\
\text { FISH: } \\
\text { MDM2 amplification }\end{array}$ & marginal excision & $\mathrm{No} / 12$ \\
\hline $\begin{array}{l}\text { Dworak } \\
{[31], 2018}\end{array}$ & 12 & $35 / \mathrm{M}$ & $\begin{array}{l}\text { proptosis, diplopia, } \\
\text { extraocular motility } \\
\text { restriction }\end{array}$ & ATL/WDL & $\begin{array}{l}\text { FISH: } \\
M D M 2 \text { amplification }\end{array}$ & $\begin{array}{l}\text { observation } \\
\text { (exenteration recommended) }\end{array}$ & No follow-up \\
\hline $\begin{array}{l}\text { McKey } \\
{[5], 2019}\end{array}$ & 13 & $22 / \mathrm{F}$ & $\begin{array}{l}\text { diplopia, subconjunctival mass, } \\
\text { proptosis }\end{array}$ & ATL/WDL, lipoma-like & $\begin{array}{l}\text { FISH: } \\
M D M 2 \text { and } C D K 4 \\
\text { amplification }\end{array}$ & debulking & Yes $(\times 1) / 108$ \\
\hline Our study & 14 & $26 / \mathrm{F}$ & proptosis & $\begin{array}{l}\text { ATL/WDL with abundant } \\
\text { myxoid stroma; recurrent } \\
\text { tumor with small foci of DDL }\end{array}$ & $\begin{array}{l}\text { FISH: } M D M 2 \text {, } \\
C D K 4 \text {, and DDIT3 } \\
\text { amplification }\end{array}$ & debulking & Yes $(\times 1) / 3$ \\
\hline
\end{tabular}

A summary is provided here of clinically and histopathologically well-documented cases of ATL/WDL (adapted from [5]). Pt, patient; M, male; F, female; IHC, immunohistochemistry; ATL/WDL, atypical lipomatous tumor/well-differentiated liposarcoma; DDL, dedifferentiated liposarcoma; LR, lateral rectus; SR, superior rectus, XRT, external-beam radiotherapy. 


\section{Discussion}

Liposarcoma is the most common soft-tissue sarcoma in adults, with ALT/WDL comprising $40-45 \%$ of all liposarcomas. Approximately $75 \%$ of ALT/WDL occurs in the lower extremities and $20 \%$ is found in the retroperitoneum [2]. ALT/WDL is uncommon in the orbit with only 20 cases reported in the literature. Similar to the presentation in our patient, orbital ALT/WDL typically manifests with painless, progressive proptosis, induced by an intraconal or extraconal mass which can be circumscribed or infiltrative (Table 1) [5].

Histopathologically, ALT/WDL is characterized by a relatively mature adipocytic proliferation that can resemble lipoma, and, less frequently, may demonstrate spindle/ sclerosing and inflammatory morphologic patterns. Focal adipocytic nuclear atypia and hyperchromasia, with frequent multinucleated or large pleomorphic stromal cells, are consistent findings. Lipoblasts in varying numbers can also be seen but are not necessarily diagnostic of liposarcoma, and their absence does not necessarily exclude ALT/WDL $[2,3,5]$. Myxoid stroma can be abundant in ALT/WDL, leading to the consideration of myxoid liposarcoma and other tumors with a myxoid matrix [2-4].

Recognition of distinct recurrent molecular genetic alterations in ALT/WDL, DDL, and myxoid liposarcoma, that involve the MDM2, CDK4, HMGA2, and DDIT3 genes in the 12q13-15 region that regulate apoptotic, cellproliferative, and lipogenic pathways, has improved our ability to discriminate between these neoplasms [2-4]. ALT/WDL and DDL harbor consistent amplification of MDM2 in the 12q13-15 region, corresponding to supernumerary ring and giant marker chromosomes. An MDM2 immunohistochemical stain can be used as a surrogate marker for MDM2 amplification. However, molecular genetic studies remain the gold standard of ALT/ WDL and DDL diagnosis [2-5].

Myxoid liposarcoma accounts for 15-20\% of all liposarcomas and typically occurs in the deep soft tissues of the extremities in young adults. This neoplasm is characteristically composed of uniform, round-to-oval, primitive cells, with variable lipogenic differentiation and a variable number of signet-ring cell lipoblasts in an abundant myxoid stroma with pseudoalveolar pools of mucin and a characteristic branching vascular pattern [2]. Myxoid liposarcoma lacks $M D M 2$ amplification, and, conversely, demonstrates a rearrangement involving the DDIT3 gene at $12 \mathrm{q} 13$ with either the FUS gene on 16p11 in $95 \%$ of cases or the EWSR 1 gene on $22 \mathrm{q} 12$ in the remaining 5\% [2-4]. Interestingly, a recent study demonstrated DDIT3 amplification, rather than rearrangement, in $75 \%$ of myxoid liposarcomalike DDL [6]. Although DDIT3 amplification has, to our knowledge, not yet been specifically identified in ALT/ WDL with myxoid stroma, it may have similarly contributed to the myxoid liposarcoma-like morphology of the well-differentiated tumor of our patient. The presence of MDM2 amplification in this case, a feature not found in myxoid liposarcoma, strongly supports the diagnosis of ALT/WDL and is also compatible with evolution into DDL.

A recent retrospective review of published reports on a total of 37 cases of orbital liposarcoma revealed the histopathologic subtype as myxoid $(n=21,57 \%)$, ALT/WDL $(n=11,30 \%)$, and pleomorphic $(n=11,11 \%)$ [1]. However, critical review of histopathologic descriptions and supporting photomicrographs of previously reported myxoid liposarcoma (Table 2) suggest that some of the presumed orbital myxoid liposarcomas likely represented a myxoid change in ALT/WDL, DDL, or pleomorphic liposarcoma [1, 7-19]. Notably, only 1 previously reported tumor diagnosed as mixed myxoid liposarcoma and WDL was evaluated by molecular methods, and it reportedly lacked the translocations seen in myxoid liposarcoma, suggesting that it was more likely WDL or DDL with variably myxoid stroma [18]. None of the reported cases of orbital myxoid liposarcoma were evaluated with immunohistochemical or molecular genetic studies targeting MDM2 and DDIT3 [1, 8-19]. Additionally, 2 patients diagnosed with orbital myxoid liposarcoma were noted to have Li-Fraumeni syndrome caused by mutation in TP53, a molecular genetic event that is more commonly seen in ALT/WDL, DDL, and pleomorphic liposarcoma, as opposed to myxoid liposarcoma [2]. These findings underscore the difficulty of accurate morphologic diagnosis of liposarcoma and the need for genetic confirmation in all cases. In fact, one might question the frequency of myxoid liposarcoma in the orbital region.

Accurate differentiation between ALT/WDL and myxoid liposarcoma has important prognostic and therapeutic implications. ALT/WDL is characterized by locally aggressive behavior, with a propensity for recurrence following incomplete excision, and no risk of metastasis unless evolution into DDL occurs. Transformation into DDL occurs in $5-15 \%$ of all ALT/WDL cases, generally at 7 -8 years following diagnosis, with lower rates in the orbit than in the retroperitoneum and deeper anatomic locations $[2,5]$. Recognition of the indolent behavior and favorable prognosis of orbital ALT/WDL has led to a recent trend of globe-salvaging resection in favor of traditional orbital exenteration [5]. The role for globe-preserving therapies such as targeted radiotherapy and adjuvant chemotherapy in orbital liposar- 
Table 2. Clinical and pathologic features of previously reported orbital myxoid liposarcoma

\begin{tabular}{|c|c|c|c|c|c|c|c|c|}
\hline $\begin{array}{l}\text { First author } \\
\text { [ref.], year }\end{array}$ & $\begin{array}{l}\text { Pt } \\
\text { No. }\end{array}$ & $\begin{array}{l}\text { Age, } \\
\text { years/sex }\end{array}$ & $\begin{array}{l}\text { Presenting signs } \\
\text { and symptoms }\end{array}$ & Diagnosis & Histopathology & $\begin{array}{l}\mathrm{IHC} / \\
\text { molecular } \\
\text { studies }\end{array}$ & Management & $\begin{array}{l}\text { Recurrence?/ } \\
\text { follow-up, } \\
\text { months }\end{array}$ \\
\hline $\begin{array}{l}\text { Blodi } \\
{[9], 1969}\end{array}$ & 1 & n.a. & $\begin{array}{l}\text { no clinical } \\
\text { history provided }\end{array}$ & $\begin{array}{l}\text { myxoid } \\
\text { liposarcoma }\end{array}$ & $\begin{array}{l}\text { Spindle or stellate cells loosely or } \\
\text { haphazardly arranged among fine collagen } \\
\text { fibrils in abundant mucoid ground } \\
\text { substance }\end{array}$ & none & n.a. & n.a. \\
\hline $\begin{array}{l}\text { Naeser } \\
{[10], 1982}\end{array}$ & 2 & $58 / \mathrm{F}$ & proptosis & $\begin{array}{l}\text { myxoid } \\
\text { liposarcoma }\end{array}$ & $\begin{array}{l}\text { Predominantly spindle cells with small and } \\
\text { dense nuclei in loosely arranged mucoid } \\
\text { matrix with rich capillary network }\end{array}$ & none & exenteration & $\mathrm{No} / 42$ \\
\hline $\begin{array}{l}\text { Malan } \\
{[11], 1983}\end{array}$ & 3 & $15 / \mathrm{F}$ & $\begin{array}{l}\text { pain, proptosis, } \\
\text { diplopia }\end{array}$ & $\begin{array}{l}\text { myxoid } \\
\text { liposarcoma }\end{array}$ & $\begin{array}{l}\text { Spindle-shaped prelipoblast cells, large } \\
\text { dedifferentiated adipocytes, edematous } \\
\text { stroma }\end{array}$ & none & $\begin{array}{l}\text { chemoradiotherapy followed by } \\
\text { exenteration and repeated XRT }\end{array}$ & $\begin{array}{l}\text { Yes }(\times 2) \text {, fatal at } 30 \\
\text { months from } \\
\text { diagnosis }\end{array}$ \\
\hline \multirow[t]{2}{*}{$\begin{array}{l}\text { Lane } \\
{[8], 1988}\end{array}$} & 4 & $22 / \mathrm{F}$ & \multirow{2}{*}{$\begin{array}{l}\text { proptosis, } \\
\text { diplopia } \\
\text { lower-eyelid } \\
\text { swelling }\end{array}$} & \multirow{2}{*}{$\begin{array}{l}\text { myxoid } \\
\text { liposarcoma } \\
\text { myxoid } \\
\text { liposarcoma }\end{array}$} & $\begin{array}{l}\text { Loose myxoid stroma infiltrated by } \\
\text { adipocytes and spindle cells }\end{array}$ & none & \multirow{2}{*}{$\begin{array}{l}\text { XRT, radical exenteration } \\
\text { including adjacent sinuses } \\
\text { subtotal excision }\end{array}$} & $\mathrm{No} / 24$ \\
\hline & 5 & $71 / \mathrm{F}$ & & & $\begin{array}{l}\text { Delicate vascular channels, lipoblasts, few } \\
\text { mitoses, some giant and pleomorphic cells } \\
\text { in myxoid stroma }\end{array}$ & none & & $\mathrm{No} / 24$ \\
\hline \multirow[t]{3}{*}{$\begin{array}{l}\text { Jakobiec } \\
{[12], 1989}\end{array}$} & 6 & $22 / \mathrm{F}$ & proptosis & $\begin{array}{l}\text { myxoid } \\
\text { liposarcoma }\end{array}$ & $\begin{array}{l}\text { Loose tissue with admixed spindle-shaped } \\
\text { cells and inflammatory cells, mostly mast } \\
\text { cells }\end{array}$ & none & $\begin{array}{l}\text { radical exenteration including } \\
\text { adjacent sinuses }\end{array}$ & $\mathrm{No} / 48$ \\
\hline & 7 & $57 / \mathrm{M}$ & $\begin{array}{l}\text { subconjunctival } \\
\text { mass }\end{array}$ & $\begin{array}{l}\text { myxoid } \\
\text { liposarcoma }\end{array}$ & $\begin{array}{l}\text { Prominent capillary proliferation not in } \\
\text { classic plexiform pattern, population of } \\
\text { spindle cells infiltrating mature lipocytes, } \\
\text { stringy pools of mucinous material, } \\
\text { scattered mast cells, signet-ring lipoblasts }\end{array}$ & none & exenteration & $\mathrm{No} / 42$ \\
\hline & 8 & $30 / \mathrm{F}$ & diplopia & $\begin{array}{l}\text { myxoid } \\
\text { liposarcoma }\end{array}$ & $\begin{array}{l}\text { Loose watery tissue with lobular pattern } \\
\text { created by fibrous subdivisions that } \\
\text { provided pseudocapsule, mature lipocytes } \\
\text { in myxoid matrix }\end{array}$ & none & $\begin{array}{l}\text { excision of mass and radiation, } \\
\text { repeat radiation }\end{array}$ & $\begin{array}{l}\text { Yes }(\times 1) \text { at } 23 \\
\text { months, no further } \\
\text { recurrence at } 41 \\
\text { months }\end{array}$ \\
\hline $\begin{array}{l}\text { McNab } \\
{[13], 1990}\end{array}$ & 9 & $69 / \mathrm{F}$ & proptosis & $\begin{array}{l}\text { myxoid } \\
\text { liposarcoma }\end{array}$ & $\begin{array}{l}\text { Spindle cells in a mucinous matrix, some in } \\
\text { signet-ring form, numerous capillaries, } \\
\text { nuclear hyperchromatism with scattered } \\
\text { enlarged cells }\end{array}$ & none & exenteration & $\mathrm{No} / 13$ \\
\hline $\begin{array}{l}\text { Favrot } \\
{[14], 1994}\end{array}$ & 11 & $31 / \mathrm{F}$ & $\begin{array}{l}\text { decreased } \\
\text { vision, pain }\end{array}$ & $\begin{array}{l}\text { myxoid } \\
\text { liposarcoma }\end{array}$ & $\begin{array}{l}\text { Well-differentiated lipoblasts, capillaries in } \\
\text { loose myxoid stroma. Pleomorphic, highly } \\
\text { cellular, poorly differentiated areas with } \\
\text { multinucleated cells also in myxoid stroma }\end{array}$ & none & $\begin{array}{l}\text { radical orbital exenteration, } \\
\text { anterior skull base resection, } \\
\text { XRT }\end{array}$ & No follow-up \\
\hline $\begin{array}{l}\text { Sabb } \\
{[15], 1996}\end{array}$ & 12 & $45 / \mathrm{F}$ & $\begin{array}{l}\text { pain, lower-lid } \\
\text { swelling }\end{array}$ & $\begin{array}{l}\text { myxoid } \\
\text { liposarcoma }\end{array}$ & $\begin{array}{l}\text { Homogenous spindle-cell tumor with } \\
\text { myxoid pattern, small cells with dark } \\
\text { nuclei resembling mature adipocytes, } \\
\text { prominent vascular pattern in areas, no } \\
\text { mitotic activity or necrosis }\end{array}$ & none & exenteration & No follow-up \\
\hline $\begin{array}{l}\text { Cockerham } \\
{[16], 1998}\end{array}$ & 13 & $35 / \mathrm{M}$ & $\begin{array}{l}\text { proptosis, EOM } \\
\text { restriction }\end{array}$ & $\begin{array}{l}\text { myxoid } \\
\text { liposarcoma }\end{array}$ & $\begin{array}{l}\text { Lipoblasts, plexiform capillaries, fibrous } \\
\text { septa and abundant extracellular myxoid } \\
\text { material }\end{array}$ & none & exenteration, XRT & Yes $(\times 1) / 60$ \\
\hline $\begin{array}{l}\text { Wagle } \\
\text { [17], } 1999\end{array}$ & 14 & $41 / \mathrm{M}$ & proptosis & $\begin{array}{l}\text { myxoid } \\
\text { liposarcoma }\end{array}$ & $\begin{array}{l}\text { Mostly well-differentiated lipocytes } \\
\text { resembling normal fat except for increased } \\
\text { population of spindle cells in loose myxoid } \\
\text { matrix with fibrous tissue septa. Low } \\
\text { mitoses, no necrosis }\end{array}$ & none & exenteration & No \\
\hline \multirow[t]{4}{*}{$\begin{array}{l}\text { Madge } \\
{[1], 2010}\end{array}$} & 16 & $23 \mathrm{~F}$ & $\begin{array}{l}\text { proptosis, upper-eyelid } \\
\text { swelling }\end{array}$ & $\begin{array}{l}\text { myxoid } \\
\text { liposarcoma }\end{array}$ & $\begin{array}{l}\text { Heterogenous appearance, some portions } \\
\text { of the specimen appearing myxoid and } \\
\text { others pleomorphic in nature, of } \\
\text { intermediate grade }\end{array}$ & $\begin{array}{l}\text { Li-Fraumeni } \\
\text { syndrome }\end{array}$ & $\begin{array}{l}\text { chemotherapy, radiation, } \\
\text { exenteration }\end{array}$ & Yes $(\times 3) / 20$ \\
\hline & 17 & $38 / \mathrm{M}$ & \multirow{3}{*}{$\begin{array}{l}\text { proptosis, } \\
\text { diplopia } \\
\text { diplopia, } \\
\text { decreased vision, } \\
\text { proptosis, anosmia } \\
\text { decreased vision, } \\
\text { periorbital swelling }\end{array}$} & \multirow{2}{*}{$\begin{array}{l}\text { myxoid } \\
\text { liposarcoma } \\
\text { myxoid } \\
\text { liposarcoma }\end{array}$} & Lipocytes in myxoid stroma & none & \multirow{2}{*}{$\begin{array}{l}\text { excision of mass } \times 8 \text {, } \\
\text { chemotherapy, exenteration } \\
\text { exenteration, XRT }\end{array}$} & Yes $(\times 9) / 174$ \\
\hline & 18 & $40 / \mathrm{M}$ & & & $\begin{array}{l}\text { Lipoblasts in mucoid matrix with capillary } \\
\text { network }\end{array}$ & none & & No follow-up \\
\hline & 19 & $32 / \mathrm{F}$ & & $\begin{array}{l}\text { myxoid } \\
\text { liposarcoma }\end{array}$ & $\begin{array}{l}\text { Gelatinous mucoid tissue with lipoblasts } \\
\text { with characteristic scalloped edges, } \\
\text { signet-ring appearance, lying in mucoid } \\
\text { matrix }\end{array}$ & $\begin{array}{l}\text { Li-Fraumeni } \\
\text { syndrome }\end{array}$ & $\begin{array}{l}\text { chemoradiotherapy, } \\
\text { exenteration }\end{array}$ & $\mathrm{No} / 6$ \\
\hline $\begin{array}{l}\text { Al-Qahtani } \\
{[18], 2011}\end{array}$ & 20 & $36 / \mathrm{M}$ & proptosis, pain & $\begin{array}{l}\text { mixed type } \\
\text { liposarcoma, } \\
\text { WDL and } \\
\text { myxoid }\end{array}$ & $\begin{array}{l}\text { Lobular tumor consisting of proliferating } \\
\text { spindle-shaped cells with several lipoblasts } \\
\text { suspended within myxoid-rich matrix and } \\
\text { complex vascular system; rare mitosis }\end{array}$ & $\begin{array}{l}\text { negative } \\
\text { for trans- } \\
\text { locations } \\
\text { associated } \\
\text { with myxoid } \\
\text { liposarcoma }\end{array}$ & $\begin{array}{l}\text { excision of mass, } \\
\text { exenteration }\end{array}$ & Yes $(\times 1) / 12$ \\
\hline \multirow[t]{2}{*}{$\begin{array}{l}\text { Khurana } \\
{[19], 2014}\end{array}$} & 22 & $50 / \mathrm{F}$ & \multirow{2}{*}{$\begin{array}{l}\text { proptosis, EOM } \\
\text { restriction, } \\
\text { decreased vision } \\
\text { pain, proptosis, } \\
\text { decreased vision }\end{array}$} & $\begin{array}{l}\text { myxoid } \\
\text { liposarcoma }\end{array}$ & $\begin{array}{l}\text { Delicate vascular channels, characteristic } \\
\text { lipoblasts, very few mitoses, some giant and } \\
\text { pleomorphic cells }\end{array}$ & S-100(+) & exenteration & $\mathrm{No} / 24$ \\
\hline & 23 & $40 / \mathrm{M}$ & & $\begin{array}{l}\text { myxoid } \\
\text { liposarcoma }\end{array}$ & $\begin{array}{l}\text { Characteristic lipoblasts in } \\
\text { delicate capillary network }\end{array}$ & none & exenteration & $\mathrm{No} / 48$ \\
\hline
\end{tabular}

A summary is provided here of clinically and histopathologically well-documented cases of myxoid liposarcoma. Pt, patient; M, male; F, female; n.a., not available; EOM, extraocular muscle; IHC, immunohistochemistry; XRT, external-beam radiotherapy. 
coma is not well-established [1]. Our patient was noted to have small foci of DDL 3 months following the initial debulking surgery. The close temporal relationship between the ALT/WDL and DDL in this case suggests that the DDL component was likely present in the tumor at the onset but perhaps not sampled in the original biopsy.

When compared to ALT/WDL, myxoid liposarcoma has potential for metastasis, which is grade-dependent, ranging from $<10 \%$ to up to $60 \%$, with patient survival influenced by the completeness of surgical excision $[2,20]$. Nonorbital myxoid liposarcoma is typically managed by complete excision with or without radiotherapy [20]. Chemotherapy is generally reserved for patients with unresectable or large tumors $(>5 \mathrm{~cm})$ and high-grade tumors [20]. Given the diagnostic controversy surrounding orbital myxoid liposarcoma, the clinical course, prognosis, and optimal management of this neoplasm in the orbital region are not clear.

The improved understanding of molecular genetic events involved in the development of various types of liposarcoma might open doors for targeted therapies, which may be particularly valuable in patients with unresectable or metastatic tumors and in situations when radical surgery may be visually debilitating, as in our monocular patient. Agents targeting MDM2, CDK4, and the molecular pathways influenced by DDIT3-FUS gene fusion are currently being tested in preclinical studies and early clinical trials and may play an increasingly important role in the management of ALT/WDL, DDL, and myxoid liposarcoma in the future [21,22].

In addition to the complexity of the histopathologic diagnosis of lipomatous tumors, this case illustrates the longterm management challenges of patients with hereditary retinoblastoma. Although the 5-year survival rate for retinoblastoma has increased to $97 \%$, patients with hereditary retinoblastoma have a greatly increased incidence of secondary malignancy, especially sarcoma, including liposarcoma [23]. The propensity for second malignancies is partly due to germline mutations in the RB1 gene, and is further increased in a dose-dependent fashion by radiotherapy and chemotherapy with alkylating agents [23]. Recent studies have explored the potential link between specific germline RB1 mutations and second malignancies. Specifically, the $\mathrm{C}>\mathrm{T}$ transition nonsense mutation, identified in the $R B 1$ gene of our patient, has been associated with a higher risk of soft-tissue sarcoma, and may have contributed to the development of bilateral sarcoma $[24,25]$.

In conclusion, orbital liposarcoma is an uncommon neoplasm which can complicate the clinical course of patients with germline retinoblastoma. Accurate subtype classification is critical in determining prognosis and management. Recent advances in molecular genetics and cytogenetics have greatly improved our ability to distinguish between liposarcoma subtypes and other simulating lesions. Orbital exenteration for ALT/WDL provides the best chance of cure, but debulking and globe preservation may be reasonable in cases where vision is paramount. Patients managed by globe-preserving therapies need to be observed closely for recurrence and the potential evolution into DDL.

\section{Statement of Ethics}

Institutional Review Board approval was waved for this retrospective case report study. The study was performed in accordance with HIPAA guidelines and in compliance with the tenets of Declaration of Helsinki.

\section{Disclosure Statement}

The authors have no conflicts of interest to declare.

\section{Funding Sources}

There was no funding.

\section{Author Contributions}

All authors contributed to the data acquisition, data analysis, drafting, and final approval of the manuscript.

\section{References}

1 Madge SN, Tumuluri K, Strianese D, Bonavolonta P, Wilcsek G, Dodd TJ, et al. Primary orbital liposarcoma. Ophthalmology. 2010 Mar;117(3):606-14.

2 Fletcher CD, Hogendoorn P, Mertens F. WHO Classification of Tumours of Soft Tissue and Bone. 4th edition, revised. Lyon: IARC Press; 2013.
3 Dei Tos AP. Liposarcomas: diagnostic pitfalls and new insights. Histopathology. 2014 Jan; 64(1):38-52.

4 Sioletic S, Dal Cin P, Fletcher CD, Hornick JL. Well-differentiated and dedifferentiated liposarcomas with prominent myxoid stroma: analysis of 56 cases. Histopathology. 2013 Jan; 62(2):287-93.
5 McKey K, Zhang PJ, Shields CL, Lally SE, Eagle RC Jr, Milman T. Orbital Atypical Lipomatous Tumor/Well-Differentiated Liposarcoma Masquerading as Pleomorphic Lipoma: A Diagnostic Challenge. Ophthal Plast Reconstr Surg. 2019 Mar;35(3):e76-80. 
6 Mantilla JG, Ricciotti RW, Chen EY, Liu YJ, Hoch BL. Amplification of DNA damage-inducible transcript 3 (DDIT3) is associated with myxoid liposarcoma-like morphology and homologous lipoblastic differentiation in dedifferentiated liposarcoma. Mod Pathol. 2019 Apr;32(4):585-92.

7 Cai YC, McMenamin ME, Rose G, Sandy CJ, Cree IA, Fletcher CD. Primary liposarcoma of the orbit: a clinicopathologic study of seven cases. Ann Diagn Pathol. 2001 Oct;5(5):255-66.

8 Lane CM, Wright JE, Garner A. Primary myxoid liposarcoma of the orbit. Br J Ophthalmol. 1988 Dec;72(12):912-7.

9 Blodi FC. Unusual orbital neoplasms. Am J Ophthalmol. 1969 Sep;68(3):407-12.

10 Naeser P, Moström U. Liposarcoma of the orbit: a clinicopathological case report. Br J Ophthalmol. 1982 Mar;66(3):190-3.

11 Malan P, Baldet P, Arnaud B. Primary orbital liposarcoma: clinicopathologic case report and review of the literature. Orbit. 1983;2(2): 99-105.

12 Jakobiec FA, Rini F, Char D, Orcutt J, Rootman J, Baylis $\mathrm{H}$, et al. Primary liposarcoma of the orbit. Problems in the diagnosis and management of five cases. Ophthalmology. 1989 Feb;96(2):180-91.

13 McNab AA, Moseley I. Primary orbital liposarcoma: clinical and computed tomographic features. Br J Ophthalmol. 1990 Jul;74(7): 437-9.

14 Favrot SR, Ridley MB, Older JJ, Szakacs JE. Orbital liposarcoma. Otolaryngol Head Neck Surg. 1994 Jul;111(1):111-5.

15 Sabb PC, Syed NA, Sires BS, Lemke BN, Dortzbach RK, Albert DM. Primary orbital myxoid liposarcoma presenting as orbital pain. Arch Ophthalmol. 1996 Mar;114(3):353-4.
16 Cockerham KP, Kennerdell JS, Celin SE, Fechter HP. Liposarcoma of the orbit: a management challenge. Ophthal Plast Reconstr Surg. 1998 Sep;14(5):370-4.

17 Wagle AM, Biswas J, Subramaniam N, Mahesh L. Primary liposarcoma of the orbit: a clinicopathological study. Orbit. 1999 Mar; 18(1):33-6.

18 Al-Qahtani AA, Al-Hussain H, Chaudhry I, El-Khamary S, Alkatan HM. Primary orbital liposarcoma: histopathologic report of two cases. Middle East Afr J Ophthalmol. 2011 Oct;18(4):314-6.

19 Khurana S, Gupta AK, Sen S, Kashyap S. Primary liposarcoma of the orbit. Indian J Pathol Microbiol. 2014 Oct-Dec;57(4):617-9.

20 Muratori F, Bettini L, Frenos F, Mondanelli N, Greto D, Livi L, et al. Myxoid Liposarcoma: Prognostic Factors and Metastatic Pattern in a Series of 148 Patients Treated at a Single Institution. Int J Surg Oncol. 2018 May;2018:8928706.

21 Nassif NA, Tseng W, Borges C, Chen P, Eisenberg B. Recent advances in the management of liposarcoma [version 1;referees: 2 approved]. F1000 Res. 2016 Dec;5:2907.

22 Trautmann M, Menzel J, Bertling C, Cyra M, Isfort I, Steinestel K, et al. FUS-DDIT3 Fusion Protein-Driven IGF-IR Signaling is a Therapeutic Target in Myxoid Liposarcoma. Clin Cancer Res. 2017 Oct;23(20): 6227-38.

23 Kleinerman RA, Tucker MA, Abramson DH, Seddon JM, Tarone RE, Fraumeni JF Jr. Risk of soft tissue sarcomas by individual subtype in survivors of hereditary retinoblastoma. J Natl Cancer Inst. 2007 Jan;99(1): 24-31.
24 Chaussade A, Millot G, Wells C, Brisse H, Laé $\mathrm{M}$, Savignoni A, et al. Correlation between RB1germline mutations and second primary malignancies in hereditary retinoblastoma patients treated with external beam radiotherapy. Eur J Med Genet. 2019 Mar;62(3): 217-23.

25 Dommering CJ, Marees T, van der Hout AH, Imhof SM, Meijers-Heijboer H, Ringens $\mathrm{PJ}$, et al. RB1 mutations and second primary malignancies after hereditary retinoblastoma. Fam Cancer. 2012 Jun;11(2):22533.

26 Stiglmayer N, Jandrokovicć S, Miklicć P, Hutinec Z. Atypical lipoma: well-differentiated liposarcoma of the orbit with dedifferentiated areas. Orbit. 2003 Dec;22(4):311-6.

27 Rosner M, Yosepovich A, Paul M, Rosen N, Perelman M. Orbital well-differentiated liposarcoma demonstrating chromosomal imbalances. Eye (Lond). 2006 Jan;20(1): 126-8.

28 Jakobiec FA, Nguyen J, Bhat P, Fay A. MDM2positive atypical lipomatous neoplasm/welldifferentiated liposarcoma versus spindle cell lipoma of the orbit. Ophthal Plast Reconstr Surg. 2010 Nov-Dec;26(6):413-5.

29 Torrado CS, Zaldibar NM, Velasco-Benito V, Fernández-Hermida R. Primary orbital liposarcoma. J Craniofac Surg. 2011 May;22(3): 1139-41.

30 Vrcek I, Hogan RN, Gilliland G. Orbital liposarcoma masquerading as a hemangioma. Proc Bayl Univ Med Cent. 2014 Oct;27(4):359-60.

31 Dworak DP, Patel SA, Chennuri R, Falco D. Primary Atypical Lipomatous Tumor of the Orbit: A Case Report. J Ophthalmic Vis Res. 2018 Jan-Mar;13(1):78-80. 